\title{
MULTIKULTURALISME DI INDONESIA
}

Oleh : Efit Fitria Agustianty

efitfitriaagustianty@gmail.com

\begin{abstract}
Abstrak
Penelitian ini bertujuan untuk mengkaji dan menganalisis multikulturalisme di Indonesia dilihat dari keragaman nilai-nilai budaya di Indonesia sebagai bentuk dari hasil karya masyarakat yang kreatif.

Penelitian ini menggunakan metode penelitian kualitatif dengan pendekatan deskriptif analisis yaitu mendeskripsikan multikulturalisme di Indonesia dilihat dari keragaman nilai-nilai budaya di Indonesia sebagai bentuk dari hasil karya masyarakat yang kreatif. Sumber data yang digunakan dalam penelitian ini adalah literature yang berkaitan dengan multicultural di Indonesia. Analisis data dilakukan melalui reduksi data, sajian data dan kesimpulan atau verifikasi.

Hasil penelitian menujukan multikulturalisme sebagai pendekatan dan sebagai Kebijakan Nasional Sebagaimana dikemukakan di atas multikulturalisme adalah suatu ideologi jalan keluar dari persoa lan mundurnya kekuatan integrasi dan kesadaran nasionalisme suatu bangsa sebagai akibat dari perubahan-perubahan di tingkat global. Indonesia.

Kata Kunci: multikularisme, Indonesia
\end{abstract}

\section{Abstract}

This study aims to analyze multiculturalism in Indonesia in terms of the diversity of cultural values in Indonesia as a form of creative community work.

This study uses a qualitative research method with a descriptive analysis approach, which describes multiculturalism in Indonesia as seen from the diversity of cultural values in Indonesia as a form of creative community work. The data source used in this study is literature related to multiculturalism in Indonesia. Data analysis was carried out through data reduction, data presentation and conclusions or verification.

The research results point to multiculturalism as an approach and as a National Policy. As stated above, multiculturalism is an ideological way out of the problem of the decline in the forces of integration and awareness of nationalism of a nation as a result of changes at the global level. Indonesia.

Keyword: multiculturalism, Indonesia

\section{A. Pendahuluan}

Indonesia merupakan negara yang memiliki beragam kebudayaan, sehingga Indonesia dikategorikan negara multikultural. Masyarakat multikultural merupakan masyarakat yang terdiri dari berbagai macam suku bangsa dan budaya. Faktor utama yang mendorong terbentuknya multikulturalisme adalah latar belakang (historis), kondisi geografis, dan keterbukaan terhadap kebudayaan luar. Dalam konteks ini, multikulturalisme masyarakat dapat memunculkan sifat-sifat tertentu dalam kelompok masyarakat yang ada. Sifat-sifat tersebut diantara lain dapat terjadi segmentasi ke dalam bentuk-bentuk kelompok subkebudayaan yang berbeda satu sama lain, menciptakan struktur sosial yang terbagi dalam lembaga yang bersifat non komplementer, kurang mengembangkan konsesus diantara anggota terhadap nilai-nilai yang bersifat dasar, integrasi sosial tumbuh di atas paksaan dan saling ketergantungan dalam bidang ekonomi, dan yang terakhir yaitu adanya dominasi politik oleh suatu kelompok atas kelompok lainnya. 
Dalam upaya membangun intgrasi budaya dalam masyarakat Indonesia yang bersifat multicultural, maka diperlukan pengembangan pendekatan multikultural yang didasarkan pada tiga prinsip pembangunan ingeritas bangsa. Isu-isu politik kebudayaan mengemuka dan berkembang cepat semenjak reformasi digulirkan pada tahun 1998. Setelah isu demokrasi yang diwujudkan dalam bentuk pelimpahan sebagian kekuasaan pusat ke daerah-daerah yang dikenal sebagai otonomi daerah mulai tahun 1999, isu multikulturalisme muncul pada tahun 2002 sebagai alternatif yang kuat untuk menjadi perekat baru kesatuan bangsa. Isu multikulturalisme muncul sebagai akibat dari kesadaran bahwa kesatuan bangsa dan integrasi nasional yang selama ini dipelihara berdasarkan politik kebudayaan seragam dianggap semakin kurang relevan dengan kondisi dan semangat otonomi daerah (desentralisasi) dan kedaerahan turut meningkat sejalan dengan reformasi politik tersebut.

Desentralisasi kekuasaan sebagai keputusan politik nasional ternyata kemudian disadari menimbulkan efek yang kontra produktif apabila dilihat dari perspektif kesatuan dan integrasi nasional suatu bangsa besar yang isinya luar biasa beranekaragam suku bangsa, agama, kemampuan ekonomi, dan bahkan ras yang tersebar dalam wilayah geografi yang sangat luas. Kontras-kontras kondisi atribut-atribut ini menjadikan semakin rumit terlebih jika isu mayoritas-minoritas, dan dominan-tidak dominan dimasukkan ke dalam wilayah analisa ini.

Kajian tentang multikulturalisme di Indonesia pada umumnya lebih memusatkan perhatian pada tujuan daripada proses untuk mencapainya. Mereka menekankan pentingnya toleransi, saling menghargai, menjaga kerukunan, menghormati perbedaan, dan sebagainya yang lebih merupakan isu falsafah humanistik-individual daripada sosialkolektif, padahal suatu model adalah berbicara tentang konsep-konsep dan strategi-strategi untuk mewujudkan konsep-konsep yang abstrak itu menjadi tindakan yang nyata dalam kehidupan masyarakat sehari-hari. Permasalahan dalam tulisan ini adalah bagaimana multikulturalisme di Indonesia.

\section{B. Pembahasan}

\section{Hakikat Multikulturalisme}

Dunia adalah tempat untuk multikulturalisme. suatu wilayah daerah dan negara adalah tempat untuk multikulturalisme. Multikulturalisme ditemukan di mana saja di permukaan bumi ini. Menurut May, multikulturalisme adalah suatu pendekatan yang menggantikan unversalisme dan yang memperkenalkan etnik yang tidak perlu dan tidak mendukung ke dalam wilayah perhatian atau kegiatan 'masyakarat sipil'.(May, 1999). Steinberg menguraikan bahwa multikulturalisme adalah suatu posisi multicultural untuk menjawab perbedaan yang berkaitan dengan rasial, golongan sosial-ekonomi, jender, bahasa, budaya, jenis kelamin, dan ketunaan. (Steinberg, 2009: 217). Calhoun, Light, \& Keller mendefinisikan bahwa multikulturalisme adalah suatu pendekatan untuk kehidupan dalam suatu masyarakat pluralistic, yang menuntut untuk menemukan cara-cara bagi orang-orang untuk memahami dan berhubungan dengan yang lainnya yang tidak tergantung kepada persamaan mereka, tetapi lebih pada penghargaan dari perbedaan mereka.(Craig;, C, 2012) menambahkan bahwa multikulturalisme lebih dari pada suatu suatu resep obat bagi hubungan antargroup yang lebih baik di Amerika Serikat. Hal itu juga dikenal sifat multikultural yang meningkat dari hubungan social dalam dunia yang lebih terpadu secara internasional dan global. (Craig; 2012: 137).

Tidak ada satu negara pun di permukaan bumi ini tanpa multikulturalisme. Hal itu dibuktikan dengan banyak negara seperti the United States, Canada, Australia, French, United Kingdom, dan Indonesia sebagai contoh negara yang ditumbuhi dengan multikulturalisme. Di negara-negara tersebut, multikulturalisme merupakan kebijakan, doktrin, filosofis, ideologi, dan sekaligus realitas yang menekankan pada karakteristik unik budaya yang berbeda asal dari berbagai etnik, agama, dan bangsa namun dengan status yang sama. Semuanya berkumpul dan hidup secara damai dan adil dalam suatu negara. Kondisi hidup seperti itu mengandung makna bahwa setiap orang atau kelompok orang harus saling menghargai perbedaan perspektif yang berkembang dan bertahan melalui berbagai macam pengalaman dan latar belakang perbedaannya. 
Manusia adalah makhluk sosial yang senantiasa bergantung pada orang lain dalam memenuhi keperluan hidupnya. Disadari atau tidak, kita semua memiliki sifat saling membutuhkan yang begitu kuat. Kebutuhan manusia dapat dipenuhi ketika antara manusia yang satu dan yang lain memiliki kesadaran dan penghormatan terhadap hak-hak orang lain Di tengahtengah masyarakat kita sering terjadi kondisi nyata yang menunjukkan adanya perbedaan dengan orang lain. Perbedaan-perbedaan itu sebenarnya hal yang sangat lumrah. Namun, perbedaan sering menimbulkan konflik dalam masyarakat. Apabila konflik tersebut tidak dapat dikendalikan, maka akan menimbulkan tindak kekerasan.

Hakikat kehidupan adalah perubahan, dan jika ada yang abadi dalam kehidupan, maka keabadian itu adalah perubahan. Kehidupan tidak pernah ada tanpa perubahan dan dalam perubahan dengan sendirinya selalu memunculkan konflik, yaitu konflik antara yang akan diubah, pengubah dan kebaruan yang lahir dari perubahan itu sendiri. Dalam kehidupan bermasyarakat, berbagai jenis konflik adalah suatu keniscayaan. Suatu masyarakat pasti pernah mengalami konflik, baik antara anggotanya maupun dengan kelompok masyarakat lain. Istilah konflik sering mengandung pengertian negatif, sebab cenderung dimaknai sebagai lawan kata dari keserasian, kedamaian, dan keteraturan. Konflik sering pula diasosiasikan dengan ancaman ataupun penggunaan kekerasan. Padahal jika dikelola dengan baik, konflik tidak selamanya diakhir dengan kekerasan

\section{Indonesia Sebagai Masyarakat Multikultural}

Indonesia dipandang sebagai contoh masyarakat majemuk dengan pandangan pluralisme karena anekaragam masyarakat dan kebudayaannya, setidak-tidaknya pada masa lampau, kurang berinteraksi satu sama lain, antara lain karena faktor geografis kepulauan. Hipotesa ahli ilmu politik seperti P. Laslettt mungkin benar bahwa sistem kekuasaan otoritarian adalah bentuk adaptif dari suatu pengaturan masyarakat majemuk dengan populasi besar yang terikat sebagai suatu negara-bangsa yang tinggal di pulau-pulau yang banyak dan tersebar luas. Melonggarkan kekuasaan otoritarian itu akan membawa persoalan besar bagi integrasi nasional. Kritik orang atas konsep pluralitas itu datang silih berganti. Namun tak satu pun yang dapat memberikan jawaban yang memuaskan. (Parekh, 1997: 87)

Konsep Furnivall itu kemudian diadopsi oleh M.G. Smith, salah seorang tokoh penting yang mengembangkan teori tentang masyarakat majemuk dalam antropologi. Smith menemukan konsep masyarakat majemuk ini penting untuk kepentingan analisa ketika untuk pertama kali ia menemukan anekaragam bentuk struktural pada masyarakat Karibia yang ditelitinya, dan kemudian membanding-bandingkannya. Menurut Smith, model masyarakat majemuk yang berlandaskan ras mengabaikan kemungkinan landasan lain, seperti kelas sosial atau agama. Smith berargumen konsep pluralisme diperlukan sebagai konsep payung yang akan digunakan secara komparatif dalam antropologi sosial. Akan tetapi, ada sebagian antropolog yang mengkritik pendapat Smith bahwa ia tidak berhasil menjelaskan konteks historis dari apa yang disebutnya masyarakat majemuk itu. Mereka mengemukakan bahwa masyarakat majemuk itu akan lebih berguna jika dilihat sebagai konteks historis daripada sebagai bentukbentuk struktural. ( Smith, 1965: 241). Sebagian antropolog lain menaruh curiga bahwa konsep masyarakat majemuk adalah konstruksi kolonial. Dengan konsep ini muncul kemudahan bagi kaum kolonialis untuk mengembangkan pengaturan keanekaragaman masyarakat dan kebudayaan dengan mengatasnamakan integrasi nasional. Dengan konsep tersebut terbuka kemungkinan potensi untuk mempraktikkan diskriminasi ras - dan kadang-kadang etnik - kategorisasi dan kodifikasi hukum. Dalam bentuk yang paling ekstrim, pluralisme rasial digunakan untuk melakukan segregasi, mengisolasi, dan menyingkirkan suatu etnik, misalnya seperti yang terjadi dalam politik perbedaan warna kulit di Afrika Selatan pada abad yang lalu.

Teori masyarakat majemuk mengabaikan ciri polietnik kebanyakan masyarakat di Dunia Ketiga sehingga kurang mempengaruhi kecenderungan kajian pascakolonial maupun kajian etnik. Seraya terus menyesuaikan diri terhadap kritik-kritik yang dilancarkan kepadanya, teori Smith mengalami kemunduran secara konseptual karena terdesak oleh 
teori-teori pluralisme kebudayaan. Berkembangnya teori-teori pluralisme kebudayaan didorong antara lain oleh (1) lahirnya negara-negara baru merdeka setelah Perang Dunia II; (2) semakin majunya teknologi komunikasi yang membebaskan masyarakat-masyarakat yang tadinya terisolasi; (3) meningkatnya kesadaran akan hak-hak sebagai bangsa dalam tatanan dunia; (4) menguat dan menyebarnya pemikiran demokrasi dan hak-hak asasi manusia di seluruh dunia. Keempat faktor pendorong ini turut melandasi dibangunnya teori-teori pluralisme kebudayaan yang secara praktis menghendaki pengakuan akan hak-hak yang sama sebagai warga kebudayaan dunia. (Geertz dan Apter, eds. 1969: 107) Pluralisme kebudayaan mencakupi gagasan bahwa perbedaan-perbedaan kebudayaan secara historis di antara berbagai masyarakat seharusnya dihargai oleh penguasa (baca: pemerintah) yang menjamin persamaan hak-hak mereka dalam masyarakat bangsa. Banyak orang kemudian berpandangan bahwa konsep pluralisme kebudayaan dapat diterapkan secara lebih universal daripada model masyarakat majemuk yang dianggap mempertahankan status-quo kekuasaan kolonial.

\section{Multikulturalisme di Indonesia}

Masyarakat Indonesia merupakan masyarakat multikultural. Dalam konteks masyarakat multkultural, upaya mencegah konflik dan adanya anggapan bahwa berkonflik merupakan hal negatif adalah sama sekali tidak relevan. Konflik bukanlah sesuatu yang dapat dihindari atau disembunyikan, tetap harus diakui keberadaannya, dikelola, dan diubah menjadi kekuatan untuk perubahan yang positif

Indonesia sebagai negara yang dihuni oleh masyarakat multikultural ditunjukkan antara lain dengan: 1) lebih dari 700 bahasa yang digunakan sehari-hari oleh setiap kelompok masyarakat pemakainya; 2) penduduk yang berbeda agama yang terdiri atas Islam, Kristen, Katolik, Hindu, dan Budha; dan 3) tradisi yang berasal dari nenek moyang setiap suku bangsa. Keberagaman masyarakat Indonesia dituangkan dalam moto nasional "Bhinneka Tunggal Ika" Moto tersebut melambangkan segala perbedaan kultural sebagai dasar kebijakan masional, doktrin, filosofis, ideologis, dan realitas sejak awal pembentukan bangsa dan Negara Indonesia.

Kemajemukan kebudayaan, negara-bangsa, dan nasionalisme. Negara-bangsa seperti Indonesia dapat dikatakan lahir dan berkembang bersamaan dengan menguatnya semangat nasionalisme di dunia yakni pada separuh pertama abad keduapuluh. Konsep nasionalisme sendiri bersendikan tiga unsur, yaitu kesadaran identitas bersama, suatu ideologi mengenai kesejarahan bersama dan rasa senasib sepenanggungan, dan adanya suatu gerakan sosial bersama demi mencapai satu tujuan bersama. Nasionalisme akan menguat apabila setiap unsur di atas mengalami peningkatan akibat adanya kekuatan dari luar yang dianggap mengancam. Hadirnya musuh dari luar, misalnya, akan dapat memperkuat nasionalisme itu.( ( Smith, 1981:. 108)

Kemajemukan kebudayaan, selain merupakan ciri yang melekat pada negara-bangsa Indonesia, juga menjadi factor pendorong dikembangkan dan diterapkannya model kebijakan masyarakat majemuk karena model itu dapat diharapkan mampu mengikat keanekaragaman yang ada. Akan tetapi, karena unsur-unsur pembentuk negara-bangsa Indonesia itu sangat beranekaragam baik secara geografi, fisik, populasi, sosial, ekonomi, dan kebudayaan, maka model kebijakan pluralistik pada masa itu dianggap paling masuk akal dan memenuhi kebutuhan sebagai pengikat kesatuan nasional yang terintegrasi. Akan tetapi, di pihak lain, unsur dari negara-bangsa yang dominan akan memperoleh posisi yang lebih diuntungkan daripada unsur yang tidak dominan. Secara teoretis, unsur dominan kerapkali diasosiasikan dengan unsur mayoritas, meskipun hal ini tidaklah selalu benar. Banyak contoh Konsep kebudayaan nasional sebagai puncak-puncak kebudayaan daerah seolah terlupakan pada masa reformasi, dan bahkan konsep ini seolah dicurigai sebagai politik kebudayaan Orde Baru yang otoritarian, di mana kontrol oleh pemerintah pusat sangat besar sehingga peluang untuk mencapai kesetaraan itu menjadi minimal. Di sisi lain, upaya menemukan model multikulturalisme Indonesia yang mempu merekat kembali persatuan dan integrasi nasional juga belum berhasil. menunjukkan bahwa unsur mayoritas bukan unsur dominan dalam ekonomi, atau unsur minoritas justru dominan dalam konteks ekonomi. Nasionalisme dalam konteks negara- 
bangsa ini sebagai landasan integrasi nasional menjadi signifikan dan instrumental dalam mempersatukan seluruh rakyat dalam batas-batas wilayah negara-bangsa, dan dalam memobilisasi rakyat untuk melawan pihak atau bangsa lain yang mengancam kedaulatan negara bangsa.

Menurut (Asmuri, 2017) bahwa kemajemukan budaya di Indonesai, karena Indonesia memiliki sekitar 300 suku, 200 bahasa daerah dan ribuan aspirasi kultural, maka dalam interaksi social dituntut untuk bersikap toleran. Sejalan dengan pendapat tersebut,(Slamet et al., 2017) menyatakan bahwa nilai-nilai pendidkan multicultural berasl dari keanekaragama budaya, bahasa, suku, agama. Sehingga untuk membangun harmoni social perlu toleransi dan menghapuskan sikap primordial.

Multikulturalisme sebagai Pendekatan dan sebagai Kebijakan Nasional Sebagaimana dikemukakan di atas multikulturalisme adalah suatu ideologi jalan keluar dari persoa lan mundurnya kekuatan integrasi dan kesadaran nasionalisme suatu bangsa sebagai akibat dari perubahan-perubahan di tingkat global. Indonesia, khususnya, mengalami perubahan tersebut belakangan ini. Setidak-tidaknya kekhawatiran terjadinya kemunduran dalam kesadaran nasionalisme telah terbukti akhir-akhir ini. Contoh yang paling nyata adalah semakin meningkatnya keinginan beberapa daerah tertentu untuk memisahkan diri dari Negara Kesatuan Republik Indonesia, meskipun sebegitu jauh pemerintah masih mampu meredam kehendak tersebut sehingga perceraian daerah-daerah tersebut belum terwujud pada saat ini. Selain itu, konflik-konflik yang terjadi akibat etidaksetaraan sosial dan ekonomi juga meningkat pada awal abad keduapuluh satu ini.

Sebagian orang berpendapat bahwa konflik-konflik itu terjadi karena kontrol negara yang selama otoriter telah melonggar, tetapi menjadikan kontrol itu kembali ketat nampaknya bukan jalan keluar yang terbaik karena Indonesia (pemerintah) akan berhadapan dengan arus kekuatan global yang lebih menyukai demokrasi, sehingga secara politik negara ini akan tersingkir dari pergaulan dunia. Akan tetapi, membuka lebih lebar lagi "keran-keran" keterbukaan juga mengandung risiko jangka panjang, yakni kemungkinan tercerai-berainya negara-bangsa ini menjadi sejumlah negara-negara yang lebih kecil. (Sunarto, 2004: 61)

Hal ini yang mendorong sebagian ahli untuk memikirkan alternatif solusi terbaik agar tidak terjebak kedalam perpecahan, yakni jalan multikulturalisme. Sebagian besar kebudayaan multikultural di dunia dapat digolongkan ke dalam salah satu dari tiga model multikulturalisme . (Parekh, 1997: 2001)

Pertama, model yang mengedepankan nasionalitas (nationality). Nasionalitas adalah sosok baru yang dibangun bersama tanpa memperhatikan anekaragam suku bangsa, agama, dan bahasa, dan nasionalitas bekerja sebagai perekat integrasi. Model ini memandang setiap orang - bukan kolektif - berhak untuk dilindungi negara sebagai warga negara. Sebagai konsekuensi dari diterapkannya model ini adalah tidak diperhatikannya akar kebudayaan etnik-etnik penyusun negara, dan menjadikannya dengan akibat yang tak terbayangkan sebelumnya. sebagai masa lampau saja. Banyak orang menuding model ini sebagai penghancur kebudayaan etnik. Model kebijakan multikulturalisme ini rentan terjerumus ke dalam kekuasaan otoritarian karena kekuasaan untuk menentukan unsurunsur integrasi nasional tersebut berada di tangan suatu kelompok elite tertentu yang menguasai negara. Nasionalitas dan nasionalisme menjadi tameng bagi para elite untuk mencapai tujuannya. Perancis adalah contoh negara yang menerapkan model ini. Di negara ini diberlakukan aturan-aturan bagi semua individu warga negara Perancis tanpa memperhatikan latar belakang etnik, dan sekaligus larangan untuk memanifestasikan identitas kebudayaan etnik atau agama ke tatanan publik. Larangan menggunakan jilbab di Perancis baru-baru ini adalah salah satu contoh bekerjanya model nasionalitas tersebut.

Kedua, model nasionalitas-etnik yang berdasarkan kesadaran kolektif etnik yang kuat yang landasannya adalah hubungan darah dan kekerabatan dengan para founders. Selain itu, kesatuan bahasa juga merupakan ciri nasional-etnik ini. Model ini dianggap sebagai model tertutup karena orang luar yang tidak memiliki sangkut paut hubungan darah dengan etnis pendiri bangsa akan tersingkir menjadi orang luar dan diperlakukan 
sebagai orang asing. Jerman dikenal sebagai bangsa yang menggunakan model multikulturalisme ini secara konsisten. Khususnya pada masa lampau, orang Jerman yang diakui sebagai bangsa Jerman adalah orang yang berasal dari etnik Arya, dan tindakan pemurnian ras Jerman menjelang Perang Dunia II adalah sebuah contoh ekstrim bekerjanya model multikulturalisme nasionalitas-etnik.

Ketiga, model multikultural-etnik yang mengakui eksistensi dan hak-hak warga etnik secara kolektif. Dalam model ini keanekaragaman menjadi realitas yang harus diakui dan diakomodasi negara, dan identitas dan asal-usul warga negara diperhatikan. Model ini diterapkan terutama oleh negara-negara yang memiliki persoalan orang pribumi (aborigines) dan orang pendatang (migrants) seperti Kanada dan Australia. Isu-isu yang muncul karena penerapan kebijakan ini tidak hanya keanekaragaman kolektif dan etnik, tetapi juga isu mayoritas-minoritas, dominan-tidak dominan. Persoalannya menjadi lebih kompleks lagi karena ternyata mayoritas tidak selalu berarti dominan, karena berbagai kasus menunjukkan bahwa minoritas justru dominan dalam ekonomi. Apabila kekuasaan negara lemah, karena prioritas kekuasaan dilimpahkan kepada anekaragam kolektif sebagai konsekuensi pengakuan negara, maka negara mungkin diramaikan oleh konflik-konflik internal berkepanjangan yang pada gilirannya akan melemahkan negara itu sendiri.

Kalau kita simak secara mendalam ketiga model di atas, nampaknya sukar bagi kita untuk mengatakan model yang mana yang sesuai untuk kondisi Indonesia karena kesesuaian dan keberlakuan model juga ditentukan oleh kondisi-kondisi obyektif Indonesia seperti geografi kepulauan yang sangat luas dengan jarak yang berjauhan satu sama lain, keanekaragaman etnik dan agama dan golongan sosial, jurang sosial-ekonomi yang semakin dalam, dan - yang tak kalah penting adalah arus besar (mainstream) politik dan ekonomi dunia global yang mempengaruhi arah kebijakan multikulturalisme di Indonesia. Model multikulturalisme seharusnya adalah suatu bentuk sosio-kultural adaptif yang sesuai dengan kondisi-kondisi menyeluruh Indonesia. Model multikulturalisme nasionalitas jelas tidak relevan dibicarakan di Indonesia, karena sejak negara ini dibangun, meskipun istilah multikulturalisme belum dikenal, bangsa Indonesia sudah jelas menyatakan dirinya "Bhinneka Tunggal Ika" yang menunjukkan diperhatikannya keanekaragaman kebudayaan. .

Patut pula kita catat bahwa ketiga model di atas berguna untuk kepentingan analisis karena ketiganya bukanlah kontras satu sama lain mengingat dalam setiap model terdapat juga unsur-unsur yang mencerminkan sebagian isi model lainya. Model multikulturalisme memiliki premis bahwa masing-masing kebudayaan diakui dan harus menjaga kebudayaannya sendiri, hidup berdampingan secara damai. Hingga kini masih terus diupayakan untuk menemukan model yang pas untuk kondisi Indonesia masa kini dan proyeksi ke masa depan. Salah satu wacana penting mengenai multikulturalisme adalah pendidikan multikultural sebagai strategi jangka panjang meskipun konsep ini mengundang banyak kontroversi pendapat. Salah satu kritiknya adalah bahwa pendidikan multikultural itu bersifat "memecah-belah" karena pengakuan terhadap hakikat hidup setiap kebudayaan akan melahirkan bentuk-bentuk yang khas pendidikan multikultural yang belum tentu berujung pada kepentingan integrasi kebudayaan secara nasional.

\section{Kesimpulan}

Berdasarkan kajian di atas dapat disimpulkan sebegai berikyut:

1. Kemajemukan kebudayaan, merupakan ciri yang melekat pada negarabangsa Indonesia, dan menjadi factor pendorong dikembangkan dan diterapkannya model kebijakan masyarakat majemuk karena model itu dapat diharapkan mampu mengikat keanekaragaman yang ada.

2. Upaya menemukan model multikulturalisme Indonesia yang mempu merekat kembali persatuan dan integrasi nasional juga belum berhasil. menunjukkan bahwa unsur mayoritas bukan unsur dominan dalam ekonomi, atau unsur minoritas 
justru dominan dalam konteks ekonomi. Nasionalisme dalam konteks negarabangsa ini sebagai landasan integrasi nasional menjadi signifikan dan instrumental dalam mempersatukan seluruh rakyat dalam batas-batas wilayah negara-bangsa, dan dalam memobilisasi rakyat untuk melawan pihak atau bangsa lain yang mengancam kedaulatan negara bangsa.

3. Multikulturalisme sebagai Pendekatan dan sebagai Kebijakan Nasional Sebagaimana dikemukakan di atas multikulturalisme adalah suatu ideologi jalan keluar dari persoa lan mundurnya kekuatan integrasi dan kesadaran nasionalisme suatu bangsa sebagai akibat dari perubahan-perubahan di tingkat global. Indonesia,

4. Konflik-konflik itu terjadi karena kontrol negara yang selama otoriter telah melonggar, tetapi menjadikan kontrol itu kembali ketat nampaknya bukan jalan keluar yang terbaik karena Indonesia (pemerintah) akan berhadapan dengan arus kekuatan global yang lebih menyukai demokrasi, sehingga secara politik negara ini akan tersingkir dari pergaulan dunia. Akan tetapi, membuka lebih lebar lagi "keran-keran" keterbukaan juga mengandung risiko jangka panjang, yakni kemungkinan tercerai-berainya negara-bangsa ini menjadi sejumlah negara-negara yang lebih kecil.

5. Alternatif solusi terbaik agar tidak terjebak kedalam perpecahan, yakni jalan multikulturalisme. Sebagian besar kebudayaan multikultural di dunia dapat digolongkan ke dalam salah satu dari tiga model multikulturalisme yaitu model yang mengedepankan nasionalitas (nationality), Model ini memandang setiap orang - bukan kolektif - berhak untuk dilindungi negara sebagai warga negara. model nasionalitas-etnik yang berdasarkan kesadaran kolektif etnik yang kuat yang landasannya adalah hubungan darah dan kekerabatan dengan para founders. Dan model multikultural-etnik yang mengakui eksistensi dan hak-hak warga etnik secara kolektif. 


\section{DAFTAR PUSTAKA}

Asmuri, A. (2017). PENDIDIKAN MULTIKULTURAL (Telaah Terhadap

Sistem Pendidikan Nasional dan Pendidikan Agama Islam). POTENSIA:

Jurnal Kependidikan Islam, 2(1), 25.

https://doi.org/10.24014/potensia.v2i1.2530

Craig;, C, et. al. (2012). sosiologi. gramedia.

May, S. (1999). Towards critical multiculturalism,Critical multiculturalism: rethinking multicultural and antiracist education. Falmer Press.

Slamet, Masrukhi, Haryono, \& Wasino. (2017). The Implementation of Multicultural Values in The Educational Insitution. The Journal of Educational Development, 5(1), 118-127.

Geertz, (1969) Clifford dan David Apter, eds. The Old Societies and New States. Chicago: Aldine Publications.

Parekh, B. National Culture and Multiculturalism. In Kenneth Thompson (ed.) Media and Cultural Regulation. London-Thousand Oaks, Calif.: Sage Publications in association with the Open University. 1997.

Smith, A.D. The Ethnic Revival. Cambridge: Cambridge University1981.

Smith, M.G. The Plural Society in the British West Indies. Berkeley: 1965.

Steinberg, R. Shirley, Perkembangan Multikulturalisme, Jakarta: Bina Ilmu, 2009,. h. 217

Sunarto, Kamanto, Russel Hiang-Khng Heng, Multicultural Education in Indonesia and Southeast Asia. Stepping into the Unfamiliar. Depok: Jurnal Antropologi Indonesia, 2004, 